\title{
EFEKTIFITAS PEMBERIAN PUPUK ORGANIK KOTORAN SAPI TERHADAP PERTUMBUHAN DAN HASIL TANAMAN KANGKUNG DARAT (Ipomoea reptans Poir)
}

\author{
Oleh : \\ Bambang Wicaksono Hariyadi \\ Fakultas Pertanian Universitas Merdeka Surabaya
}

\begin{abstract}
ABSTRAK
Kangkung darat (Ipomoea reptans Poir) merupakan tanaman yang tumbuh cepat dan merupakan salah satu sayuran khas daerah tropis. Tanaman ini merupakan sumber gizi yang relatif mudah pemeliharaannya serta cepat dapat diambil manfaatnya (Triana Kartika Santi, 2007).

Menurut Mul Mulyani Sutejo (1995) dan Rukmana (2005), pupuk kandang (pupuk organik) dapat menambah tersedianya bahan makanan (unsur hara makro dan mikro) bagi tanaman. Dengan kata lain, pupuk kandang mempunyai kemampuan mengubah berbagai faktor dalam tanah, sehingga menjadi faktor-faktor yang menjamin kesuburan tanah. Pupuk kandang dianggap sebagai pupuk lengkap karena selain menimbulkan tersedianya unsur hara bagi tanaman, juga mengembangkan kehidupan jasad renik (mikroorganisme) di dalam tanah. Jasad renik sangat penting bagi kesuburan tanah karena sisa-sisa organ tanaman dapat diubah menjadi humus dan senyawa-senyawa tertentu disintesis oleh jasad renik menjadi bahan-bahan yang berguna bagi tanaman. Lebih lanjut Syekhfani (2000) menjelaskan bahwa pupuk organik (pupuk kompos maupun pupuk kandang) memiliki sifat alami dan tidak merusak tanah, menyediakan unsur hara nakro dan mikro juga berfungsi antara lain dapat meningkatkan daya menahan air, aktifitas mikrobiologi tanah, nilai kapasitas tukar kation serta memperbaiki struktur tanah.

Tujuan Penelitian ini untuk mengetahui sejauh mana efektifitas pemberian pupuk organik kotoran sapi terhadap pertumbuhan dan hasil tanaman kangkung darat (Ipomoea reptans Poir).

Penelitian ini menggunakan Rancangan Acak Kelompok (RAK) yang terdiri dari enam (6) perlakuan dengan tiga (3) ulangan. Adapun perlakuan tersebut antara lain :

P0 = Tanpa Pupuk Organik (Kontrol); P1 = Pupuk Organik 10ton/Ha (10gr/tanaman atau 100gr/polybag); P2 = Pupuk Organik 20ton/Ha (20gr/tanaman atau 200gr/polybag); P3 = Pupuk Organik 30ton/Ha (30gr/tanaman atau 300gr/polybag); P4 = Pupuk Organik 40ton/Ha (40gr/tanaman atau 400gr/polybag); P5 = Pupuk Organik 50ton/Ha (50gr/tanaman atau 500gr/polybag).

Kesimpulannya, bahwa terdapat pengaruh yang sangat nyata terhadap tinggi tanaman, jumlah daun, berat basah per tanaman dan berat basah tanaman per polybag pada tanaman Kangkung darat akibat pemberian pupuk organik kotoran sapi. Perlakuan pemberian dosis pupuk organik kotoran sapi 50 ton/Ha menghasilkan pertumbuhan dan hasil maksimum, sedangkan untuk pertumbuhan dan hasil yang optimum (tepat guna dan menguntungkan) terhadap tanaman Kangkung Darat, ditunjukkan perlakuan pemberian dosis pupuk kotoran sapi 30 ton/Ha.
\end{abstract}

Kata Kunci : Pupuk Organik Kandang Sapi, Kangkung Darat. 


\section{PENDAHULUAN}

Kangkung darat (Ipomoea reptans Poir) merupakan tanaman yang tumbuh cepat dan merupakan salah satu sayuran khas daerah tropis. Tanaman ini merupakan sumber gizi yang relatif mudah pemeliharaannya serta cepat dapat diambil manfaatnya (Triana Kartika Santi, 2007).

Kangkung tergolong tanaman sayuran yang sangat populer, karena banyak peminatnya. Tanaman kangkung disebut juga Swamp cabbage, Water convovulus, Water spinach. Tanaman ini berasal dari India yang kemudian menyebar ke Malaysia, Burma, Indonesia, China Selatan Australia dan bagian negara Afrika. Di Indonesia, tanaman kangkung banyak ditanam di Pulau Jawa, khususnya di Jawa Barat dan Jawa Timur. Di Irian Jaya, di Kecamatan Muting, Kabupaten Merauke, tanaman kangkung merupakan lumbung hidup sehari-hari, akan tetapi di Kecamatan Darussalam, Kabupaten Aceh Besar, tanaman kangkung darat banyak ditanam penduduk untuk konsumsi keluarga maupun untuk dijual ke pasar (Zaelani Kadir, 2003).

Kebutuhan sayuran kangkung cenderung terus meningkat sejalan dengan meningkatnya kesadaran masyarakat akan pentingnya gizi dan banyaknya rumah makan yang menyajikan sayur kangkung sebagai salah satu menu mereka. Produksi kangkung di Indonesia dapat mencapai 500.000 -600.000 kg per hektar (Sutanto, 2002). Meski harga sayuran kangkung relatif murah, namun bila dibudidayakan secara intensif dan berorientasi ke arah agribisnis akan memberikan keuntungan yang cukup besar bagi petani. Peluang pemasaran kangkung makin luas, karena tidak hanya dapat dijual di pasar-pasar lokal didaerah, tetapi juga telah banyak dipesan oleh pasar-pasar swalayan. Masuknya sayuran kangkung ke pasar-pasar swalayan akan menaikkan harga jual sayuran ini (Susila, 2006).

Meningkatnya permintaan akan sayuran kangkung, tentunya perlu di imbangi dengan peningkatan produksinya. Salah satu faktor produksi yang penting didalam budidaya yang intensif adalah masalah pupuk dan pemupukan. Rendahnya efisiensi serapan unsur hara oleh tanaman pada pupuk Nitrogen dan kalsium berkisar antara 30-40 $\%$, serta 15-20\% efisiensi serapan pada pupuk phospor (Sri Adiningsih, 1995).

Tanaman tidak cukup hanya mengandalkan unsur hara dari dalam tanah saja. Oleh karena itu, tanaman perlu diberi unsur hara tambahan dari luar, yaitu berupa pupuk (Prihantoro, 2001). Upaya peningkatan efisiensi penggunaan pupuk dapat ditempuh melalui prinsip tepat dosis, tepat cara, tepat waktu aplikasi dan berimbang sesuai kebutuhan tanaman (Syafruddin dkk, 2009).

Menurut Wahyono (2012), pupuk adalah bahan dan zat makanan yang diberikan atau ditambahkan kepada tanaman dengan maksud zat makanan untuk tanah itu bertambah. Ada dua macam pupuk yaitu pupuk buatan (anorganik) dan pupuk alami (pupuk organik). Kurangnya pengetahuan petani mengenai jenis dan jumlah dosis pupuk yang dibutuhkan tanaman, merupakan persoalan juga, yang berakibat pada rendahnya peningkatan produksi tanaman persatuan luas (Lingga dan Marsono, 2007).

Menurut Loveless (1999), bahwa tanah yang baik adalah tanah yang mampu menyediakan unsur-unsur hara secara lengkap. Jika unsur-unsur dalam tanah terjadi kekurangan (tidak subur), maka akan tampak jelas dalam waktu beberapa hari muncul gejala pertumbuhan yang tidak sehat pada tanaman. Misalnya pertumbuhan kerdil, daun menguning, dan pertumbuhan kayu berlebihan, daun-daun muda yang cepat berubah menjadi hijau pucat yang lama kelamaan akan mati.

Menurut Sigit Aditama (2011), berdasarkan asal dan senyawa pembentuknya, pupuk dibedakan antara lain berupa pupuk anorganik atau mineral merupakan pupuk dari senyawa anorganik, dimana hampir semua pupuk buatan tergolong pupuk anorganik dan yang kedua adalah pupuk organik, kebanyakan pupuk alam, misal pupuk kandang, 
kompos, guano termasuk pupuk organik. Lebih lanjut Roesmarkan dan Yuwono (2002), menyebutkan bahwa berdasarkan jumlah hara yang dikandungnya, dibedakan pupuk yang hanya mengandung satu hara saja, misalnua Urea $(\mathrm{N})$, TSP $(\mathrm{P})$ dan $\mathrm{KCl}(\mathrm{K})$, dan kemudian pupuk yang mengandung dua atau lebih hara yang disebut pupuk majemuk, misalnya NPK, nitrophonska, amoniumphonska, dan lain sebagainya.

Menurut Mul Mulyani Sutejo (1995), pupuk kandang merupakan pupuk organik yang dapat menambah tersedianya bahan makanan (unsur hara) bagi tanaman yang dapat diserapnya dari dalam tanah. Dengan kata lain pupuk kandang mempunyai kemampuan mengubah berbagai faktor dalam tanah, sehingga menjadi faktor-faktor yang menjamin kesuburan tanah. Pupuk kandang dianggap sebagai pupuk lengkap karena selain menimbulkan tersedianya unsur hara bagi tanaman, juga mengembangkan kehidupan jasad renik (mikroorganisme) di dalam tanah. Jasad renik sangat penting bagi kesuburan tanah dan sisa-sisa tanaman yang dapat diubahnya menjadi humus, senyawasenyawa tertentu disintesisnya menjadi bahan-bahan yang berguna bagi tanaman.

Menurut Untung (1997), bahwa dengan pemberian dosis pupuk organik 20 ton per hektar, ternyata masih tidak dapat mensubstitusi kebutuhan nitrogen untuk pertumbuhan tanaman kangkung darat. Lebih lanjut Darwin Pangaribuan (2012) menyebutkan, bahwa bokashi pupuk kandang ayam yang dikombinasikan dengan setengah dosis pupuk anorganik rekomendasi dapat meningkatkan hasil tomat dibandingkan dengan bokashi pupuk kandang kambing, sapi dan kuda. Bokashi berbasis kotoran ternak seperti kotoran ayam, sapi, kambing dan kuda yang dikombinasikan dengan pupuk anorganik setengah dosis anjuran dapat diterapkan guna penghematan penggunaan pupuk anorganik pada budidaya tomat.

Pemupukan untuk tanaman kangkung, terdiri dari pupuk dasar, yaitu pupuk kandang yang diberikan seminggu sebelum tanam dan pupuk urea yang dicampur dengan air, kemudian disiramkan pada pangkal tanaman. Pupuk organik dibutuhkan sekitar 1020 ton per hektar dan 100-250 kg urea per hektar yang diberikan mulai tanam sampai dua minggu pertama, dengan cara disiramkan. Kurangnya pengetahuan mengenai jumlah dan jenis unsur hara yang dibutuhkan tanaman, merupakan persoalan juga, hal ini akan berakibat pada rendahnya peningkatan produksi persatuan luas (Rahmad Budiono, 2009).

Aplikasi pemupukan yang bersumber dari pupuk organik masih belum banyak dilakukan. Apalagi untuk mengetahui efisiensi (menguntungkan) dan efektifitas (tepat guna) dari penggunaan pupuk tersebut pada tanaman sayuran, termasuk tanaman kangkung. Untuk itu perlu dikaji lebih jauh penggunaan pupuk organik tersebut.

Tabel 1. Kandungan Nitrogen, Phospor dan Kalium pada Berbagai Macam Pupuk Organik Kotoran Hewan (Darwin Pangaribuan, 2012).

\begin{tabular}{|l|l|l|l|}
\hline \multicolumn{1}{|c|}{$\begin{array}{c}\text { Macam Pupuk Organik } \\
\text { Kotoran Hewan }\end{array}$} & $\begin{array}{c}\text { N-Total (\%) } \\
\text { Kejdahl }\end{array}$ & $\begin{array}{c}\text { P-Total (\%) } \\
\text { Bray }\end{array}$ & $\begin{array}{c}\text { K-Total (\%) } \\
\mathrm{NH}_{4} \mathrm{Oac}\end{array}$ \\
\hline Pupuk Organik Kotoran Ayam & 1.30 & 1.21 & 1.39 \\
\hline Pupuk Organik Kotoran Kambing & 1.12 & 0.32 & 1.07 \\
\hline Pupuk Organik Kotoran Sapi & 0.95 & 0.18 & 0.58 \\
\hline Pupuk Organik Kotoran Kuda & 0.77 & 0.56 & 0.42 \\
\hline
\end{tabular}




\section{METODE PENELITIAN}

Penelitian dilaksanakan di Kebun Percobaan Fakultas Pertanian Universitas Merdeka Surabaya, di jalan Ketintang Madya VII-2 Surabaya, Jawa Timur dengan ketinggian tempat $\pm 5 \mathrm{~m}$ diatas permukaan laut. Penelitian ini dilaksanakan bulan Januari-Februari 2015.

Bahan-bahan yang digunakan dalam penelitian ini antara lain : tanah tanam, pupuk organik kotoran sapi, pupuk Urea (Kandungan 46\% N), benih Kangkung darat. Sedangkan alat yang digunakan, antara lain : cangkul, cetok, pisau, tree pembenihan, polybag (ukuran media $5 \mathrm{~kg}$ ), label, alat pengukur penggaris, alat tulis, alat ukur berat (timbangan house dan timbangan elektrik) dan peralatan laboratorium lainnya.

Penelitian ini menggunakan Rancangan Acak Kelompok (RAK) sederhana yang terdiri dari enam (6) perlakuan dengan tiga (3) ulangan dan untuk pengamatan, masingmasing perlakuan diwakili dua (2) tanaman sampel, kemudian untuk penempatan perlakuan pada petak percobaan dilakukan secara acak.

Adapun perlakuan-perlakuan Pupuk Organik kotoran sapi terdiri dari enam (6) dosis, antara lain :

$\mathrm{P} 0=$ Tanpa Pupuk Organik (kontrol)

$\mathrm{P} 1=$ Pupuk Organik 10 ton/Ha (10 gram/tanaman atau 100 gram/polybag $)$

P2 = Pupuk Organik 20 ton/Ha (20 gram/tanaman atau 200 gram/polybag)

P3 = Pupuk Organik 30 ton/Ha (30 gram/tanaman atau 300 gram/polybag)

$\mathrm{P} 4=$ Pupuk Organik 40 ton/Ha (40 gram/tanaman atau 400 gram/polybag)

P5 = Pupuk Organik 50 ton/Ha (50 gram/tanaman atau 500 gram/polybag)

Untuk mengetahui adanya pengaruh pemberian pupuk Organik terhadap pertumbuhan dan hasil Tanaman Kangkung Darat, maka digunakan Uji F dengan taraf 5\%, yaitu Uji Analisis Sidik Ragam (ASR). Apabila dari hasil Uji F 5\% terdapat pengaruh yang nyata, maka dilanjutkan dengan Uji T (Uji Beda Nyata Terkecil) dengan taraf 5\% guna mengetahui perbedaan diantara dosis perlakuan pupuk Organik, sehingga dapat diketahui dosis perlakuan yang tepat guna (dosis efektif) dan menguntungkan (dosis efisien).

Macam variabel pengamatan pertumbuhan dan hasil Tanaman Kangkung Darat yang diamati pada penelitian ini meliputi : Tinggi Tanaman, Jumlah Daun, Berat Basah per Tanaman dan Berat Basah Tanaman per Polybag.

\section{HASIL DAN PEMBAHASAN}

\section{Tinggi Tanaman}

Hasil analisis ragam menunjukkan, bahwa perlakuan pemberian dosis pupuk organik kotoran sapi berpengaruh sangat nyata pada pengamatan tinggi tanaman selama pertumbuhan tanaman kangkung darat, yaitu pada saat tanaman umur 10 hari, 20 hari dan 30 hari setelah tanam (Lampiran 1).

Pada Tabel 1. menunjukkan, bahwa dengan meningkatnya pemberian dosis pupuk organik kotoran sapi akan diikuti pula dengan peningkatan tinggi tanaman selama pertumbuhan tanaman kangkung darat. Tinggi tanaman, terpendek (terkecil) cenderung ditunjukkan perlakuan tanpa pupuk organik $(21,89 \mathrm{~cm})$ dan secara statistik berbeda nyata dengan perlakuan pemberian dosis pupuk organik kotoran sapi lainnya. Tanaman tertinggi cenderung dicapai perlakuan pemberian dosis pupuk organik kotoran sapi 50 ton/Ha $(30,67 \mathrm{~cm})$, meskipun secara statistik tidak berbeda nyata dengan perlakuan pemberian dosis pupuk organik kotoran sapi 40 ton/Ha $(29,64 \mathrm{~cm})$, dan perlakuan pemberian dosis pupuk organik kotoran sapi 30 ton/Ha $(28,89 \mathrm{~cm})$, tetapi ketiga perlakuan 
tersebut berbeda nyata secara statistik dengan perlakuan pemberian dosis pupuk organik kotoran sapi yang lainnya.

Tabel 1. Rata-rata Tinggi Tanaman $(\mathrm{cm})$ Kangkung Darat Akibat Pengaruh Pemberian Pupuk Organik Kotoran Sapi pada Berbagai Dosis dan Umur Pengamatan

\begin{tabular}{|l|c|c|c|}
\hline \multirow{2}{*}{\begin{tabular}{c}
\multirow{2}{*}{$\begin{array}{c}\text { Perlakuan Pemberian Dosis } \\
\text { Pupuk Organik Kotoran Sapi }\end{array}$} \\
\cline { 2 - 4 }
\end{tabular}} & \multicolumn{3}{|c|}{ Rata-Rata Tinggi Tanaman $(\mathrm{cm})$} \\
\cline { 2 - 4 } & 10 hari & 20 hari & 30 hari \\
\hline P0 = Tanpa Pupuk Organik & $5,82 \mathrm{a}$ & $15,35 \mathrm{a}$ & $21,89 \mathrm{a}$ \\
\hline P1 = Pupuk Organik 10 ton/Ha & $7,64 \mathrm{~b}$ & $17,89 \mathrm{~b}$ & $25,17 \mathrm{~b}$ \\
\hline P2 = Pupuk Organik 20 ton/Ha & $9,23 \mathrm{c}$ & $18,17 \mathrm{~b}$ & $26,33 \mathrm{~b}$ \\
\hline P3 = Pupuk Organik 30 ton/Ha & $10,89 \mathrm{~d}$ & $20,33 \mathrm{c}$ & $28,89 \mathrm{c}$ \\
\hline P4 = Pupuk Organik 40 ton/Ha & $11,35 \mathrm{~d}$ & $21,67 \mathrm{~cd}$ & $29,64 \mathrm{c}$ \\
\hline P5 = Pupuk Organik 50 ton/Ha & $11,64 \mathrm{~d}$ & $22,33 \mathrm{~d}$ & $30,67 \mathrm{c}$ \\
\hline BNT 5 \% & 0,81 & 1,73 & 2,28 \\
\hline
\end{tabular}

Keterangan : Angka-angka yang didampingi huruf yang sama pada kolom yang sama tidak berbeda nyata pada Uji BNT 5\%

\section{Jumlah Daun}

Hasil analisis ragam menunjukkan, bahwa perlakuan pemberian dosis pupuk organik kotoran sapi berpengaruh sangat nyata pada pengamatan jumlah daun selama pertumbuhan tanaman kangkung darat, baik pada saat tanaman ber- umur 10 hari, 20 hari dan 30 hari setelah tanam (Lampiran 2).

Tabel 2. Rata-rata Jumlah Daun Tanaman Kangkung Darat Akibat Pengaruh Pemberian Pupuk Organik Kotoran Sapi pada Berbagai Dosis dan Umur Pengamatan.

\begin{tabular}{|l|c|c|c|}
\hline \multirow{2}{*}{$\begin{array}{c}\text { Perlakuan Pemberian Dosis Pupuk } \\
\text { Organik Kotoran Sapi }\end{array}$} & \multicolumn{3}{|c|}{ Rata-Rata Jumlah Daun Tanaman } \\
& 10 hari & 20 hari & 30 hari \\
\cline { 2 - 4 } & $3,50 \mathrm{a}$ & $5,25 \mathrm{a}$ & $8,25 \mathrm{a}$ \\
\hline P0 = Tanpa Pupuk Organik & $4,00 \mathrm{~b}$ & $6,25 \mathrm{~b}$ & $10,75 \mathrm{~b}$ \\
\hline P1 = Pupuk Organik 10 ton/Ha & $4,25 \mathrm{~b}$ & $6,50 \mathrm{~b}$ & $11,50 \mathrm{~b}$ \\
\hline P2 = Pupuk Organik 20 ton/Ha & $4,75 \mathrm{c}$ & $7,50 \mathrm{c}$ & $13,00 \mathrm{c}$ \\
\hline P3 = Pupuk Organik 30 ton/Ha & $5,00 \mathrm{c}$ & $7,75 \mathrm{c}$ & $13,75 \mathrm{c}$ \\
\hline P4 = Pupuk Organik 40 ton/Ha & $5,00 \mathrm{c}$ & $8,25 \mathrm{c}$ & $14,00 \mathrm{c}$ \\
\hline P5 = Pupuk Organik 50 ton/Ha & 0,25 & 0,75 & 1,25 \\
\hline BNT 5\% & & & \\
\hline
\end{tabular}

Keterangan : Angka-angka yang didampingi huruf yang sama pada kolom yang sama tidak berbeda nyata pada Uji BNT 5\%

Pada Tabel 2. menunjukkan, bahwa dengan meningkatnya pemberian dosis pupuk organik kotoran sapi akan diikuti pula dengan peningkatan jumlah daun selama pertumbuhan tanaman Kangkung Darat. Jumlah daun terkecil cenderung ditunjukkan perlakuan tanpa pupuk organik kotoran sapi $(8,25$ helai) dan secara statistik berbeda nyata dengan perlakuan pemberian dosis pupuk organik kotoran sapi lainnya. Jumlah daun 
terbanyak cenderung dicapai perlakuan pemberian dosis pupuk organik kotoran sapi 50 ton/Ha (14,00 helai), meskipun secara statistik tidak berbeda nyata dengan perlakuan pemberian dosis pupuk organik kotoran sapi 40 ton/Ha (13,75 helai), dan perlakuan pemberian pupuk organik kotoran sapi 30 ton/Ha (13,00 helai), tetapi ketiga perlakuan dosis pupuk tersebut berbeda nyata secara statistik dengan perlakuan pemberian dosis pupuk organik kotoran sapi lainnya.

\section{Berat Basah per Tanaman dan Berat Basah Tanaman per Polybag.}

Hasil analisis ragam menunjukkan, bahwa perlakuan pemberian dosis pupuk organik kotoran sapi berpengaruh sangat nyata pada pengamatan berat basah per tanaman dan berat basah tanaman per polybag (10 tanaman/polybag) kangkung darat (Lampiran 2).

Pada Tabel 2. menunjukkan, bahwa dengan meningkatnya pemberian dosis pupuk organik kotoran sapi akan diikuti pula dengan peningkatan berat basah per tanaman dan berat basah tanaman per polybag tanaman Kangkung Darat. Berat basah per tanaman dan berat basah tanaman per polybag terkecil cenderung ditunjukkan perlakuan tanpa pupuk organik kotoran sapi (10,30 gram dan 127,43 gram) dan secara statistik berbeda nyata dengan perlakuan pemberian dosis pupuk organik kotoran sapi lainnya. Jumlah daun terbanyak cenderung dicapai perlakuan pemberian dosis pupuk organik kotoran sapi 50 ton/Ha (23,20 gram dan 241,80 gram), meskipun secara statistik tidak berbeda nyata dengan perlakuan pemberian dosis pupuk organik kotoran sapi 40 ton/Ha $(22,70$ gram dan 237,93 gram), dan perlakuan pemberian pupuk organik kotoran sapi 30 ton/Ha (21,90 gram dan 229,10 gram), tetapi ketiga perlakuan dosis pupuk tersebut berbeda nyata secara statistik dengan perlakuan pemberian dosis pupuk organik kotoran sapi lainnya.

Tabel 3. Rata-rata Berat Basah per Tanaman dan Berat Basah Tanaman per Polybag (gram) Tanaman Kangkung Darat Akibat Pengaruh Pemberian Dosis Pupuk Organik Kotoran Sapi.

\begin{tabular}{|l|c|c|}
\hline \multirow{2}{*}{$\begin{array}{l}\text { Perlakuan Pemberian Dosis Pupuk } \\
\text { Organik Kotoran Sapi }\end{array}$} & $\begin{array}{l}\text { Rata-Rata Berat Basah (gram) } \\
\text { Tanaman Kangkung Darat }\end{array}$ \\
\cline { 2 - 3 } & Per Tanaman & Per Polybag \\
\hline P0 = Tanpa Pupuk Organik & $10,30 \mathrm{a}$ & $127,43 \mathrm{a}$ \\
\hline P1 = Pupuk Organik 10 ton/Ha & $15,70 \mathrm{~b}$ & $174,20 \mathrm{~b}$ \\
\hline P2 = Pupuk Organik 20 ton/Ha & $17,10 \mathrm{~b}$ & $191,58 \mathrm{~b}$ \\
\hline P3 = Pupuk Organik 30 ton/Ha & $21,90 \mathrm{c}$ & $229,10 \mathrm{c}$ \\
\hline P4 = Pupuk Organik 40 ton/Ha & $22,70 \mathrm{c}$ & $237,93 \mathrm{c}$ \\
\hline P5 = Pupuk Organik 50 ton/Ha & $23,20 \mathrm{c}$ & $241,80 \mathrm{c}$ \\
\hline BNT 5\% & 2,38 & 19,86 \\
\hline
\end{tabular}

Keterangan : Angka-angka yang didampingi huruf yang sama pada kolom yang sama tidak berbeda nyata pada Uji BNT 5\%

\section{KESIMPULAN DAN SARAN}

\subsection{Kesimpulan}

Berdasarkan hasil pengamatan dan pembahasan dari penelitian pengaruh pemberian dosis pupuk organik kotoran sapi terhadap pertumbuhan dan hasil tanaman Kangkung Darat (Ipomoea reptans Poir) dapat disimpulkan sebagai berikut : 
a. Terdapat pengaruh yang sangat nyata pada variabel pengamatan tinggi tanaman, jumlah daun dan berat basah per tanaman serta berat basah tanaman per polybag tanaman Kangkung Darat akibat pemberian pupuk organik kotoran sapi.

b. Perlakuan pemberian dosis pupuk organik kotoran sapi 50 ton/Ha menghasilkan pertumbuhan dan hasil maksimum, sedangkan untuk pertumbuhan dan hasil yang optimum (tepat guna dan menguntungkan) terhadap tanaman Kangkung Darat, ditunjukkan perlakuan pemberian dosis pupuk kotoran sapi 30 ton/Ha.

\subsection{Saran}

Dari kesimpulan diatas, disarankan untuk dikaji lebih lanjut pada perlakuan pemberian pupuk organik kotoran sapi dengan variasi dosis yang sama atau berbeda dalam kondisi iklim dan lokasi yang berbeda pula, agar dapat dicapai pupuk dan pemupukan yang optimum untuk seluruh tanaman sayuran.

Dosis pupuk organik kotoran sapi yang tepat guna dan menguntungkan di dalam budidaya tanaman Kangkung Darat adalah sebesar 30 ton/Ha.

\section{DAFTAR PUSTAKA}

Adji Sastrosupudi, 1999. Rancangan Percobaan Praktis Bidang Pertanian. Edisi Revisi. Kanisius, Yogyakarta. 276. Hal

Ainun Najib. 2013. Pengaruh Penggunaan Dosis Pupuk Urea dan Dosis Pupuk Kompos Terhadap Pertumbuhan dan Hasil Tanaman Sawi. UPN VETERAN, Jawa Timur. Fakultas Pertanian, Surabaya.

Hendro Sumaryono, 2004. Kunci Bercocok Tanam Sayur - sayuran penting di Indonesia. Sinar baru. Bandung.

Lingga dan Marsono, 2004. Petunjuk Penggunaan Pupuk Penebar Swadaya, Jakarta 149 Hal.

Marsusi, 2010. Budidaya Kangkung. PAUD Kalimantan Barat, Balai Pengkajian Teknologi Pertanian. Kalimantan Barat.

Prihmantoro, 2001. Hidroponik Sayur Semusim penebar. Swadaya Jakarta. 98 Halaman. Rahardi, 2000. Revolusi Hijau lawan Pertanian Organik. Penebar Swadaya Jakarta.

Rahmad Budiono, 2009. Pengaruh Pemberian Pupuk Organik dan Nitrogen terhadap Pertumbuhan dan Hasil Tanaman Kangkung Darat. Balai Pengkajian Teknologi Pertanian. Jawa Timur. Surabaya.

Roesmarkan dan Juwono, 2002. Ilmu Kesuburan Tanah. Kamisius Yogyakarta. 58 Hal. Rukmana, 2005. Bertanam Petsa dan Sawi. Penerbit Kamisius. Yogyakarta. 66 Halaman.

Sri Adiningsih, 1995. Pengelolaan Hara Terpadu untuk Mencapai Produksi Pangan yang mantap dan Akrab Lingkungan dalam Prosidina Pertemuan Teknis Penelitian Tanah dan Agroklimak. Pusat Penelitian Tanah dan Agroklimak. Bogor.

Susila. 2006. Panduan Budidaya Tanaman Sayuran. Departemen Agronomi dan Hortikultura. Institut Pertanian Bogor. Bogor. 66 hal.

Sutanto. 2002. Perapan Pertanian Organik. Penerbit Kanisius. Yogyakarta. 
DAFTAR LAMPIRAN

Lampiran 1. Analisis Ragam Rata-Rata Tinggi Tanaman Kangkung Darat pada Berbagai Umur Pengamatan

\begin{tabular}{|c|c|c|c|c|c|c|}
\hline \multicolumn{7}{|l|}{ Umur 10 Hari } \\
\hline SK & DB & JK & KT & F Hitung & F1\% & F5\% \\
\hline Perlakuan & 5 & 69,22 & 13,84 & $16,09 * *$ & 5,64 & 3,33 \\
\hline Ulangan & 2 & 0,85 & & & & \\
\hline Acak & 10 & 8,63 & 0,86 & & & \\
\hline Total & 17 & 78,70 & & & & \\
\hline \multicolumn{7}{|l|}{ Umur 20 Hari } \\
\hline SK & DB & JK & KT & F Hitung & F1\% & F5\% \\
\hline Perlakuan & 5 & 184,23 & 36,84 & $23,19 * *$ & 5,64 & 3,33 \\
\hline Ulangan & 2 & 13,75 & & & & \\
\hline Acak & 10 & 15,86 & 1,58 & & & \\
\hline Total & 17 & 213,84 & & & & \\
\hline \multicolumn{7}{|l|}{ Umur 30 Hari } \\
\hline SK & DB & JK & KT & F Hitung & F1\% & F5\% \\
\hline Perlakuan & 5 & 247,35 & 49,47 & $12,62 * *$ & 5,64 & 3,33 \\
\hline Ulangan & 2 & 6,84 & & & & \\
\hline Acak & 10 & 39,26 & 3,92 & & & \\
\hline Total & 17 & 293,45 & & & & \\
\hline
\end{tabular}

Lampiran 2. Analisis Ragam Rata-Rata Jumlah Daun Tanaman Kangkung Darat pada Berbagai Umur Pengamatan

\begin{tabular}{|c|c|c|c|c|c|c|}
\hline \multicolumn{7}{|l|}{ Umur 10 Hari } \\
\hline SK & DB & JK & KT & F Hitung & F1\% & F5\% \\
\hline Perlakuan & 5 & 9,23 & 1,84 & $6,34 * *$ & 5,64 & 3,33 \\
\hline Ulangan & 2 & 0,03 & & & & \\
\hline Acak & 10 & 2,93 & 0,29 & & & \\
\hline Total & 17 & 12,19 & & & & \\
\hline \multicolumn{7}{|l|}{ Umur 20 Hari } \\
\hline SK & $\mathrm{DB}$ & JK & KT & F Hitung & $\mathrm{F} 1 \%$ & F5\% \\
\hline Perlakuan & 5 & 34,65 & 6,93 & $7,14 * *$ & 5,64 & 3,33 \\
\hline Ulangan & 2 & 2,21 & & & & \\
\hline Acak & 10 & 9,73 & 0,97 & & & \\
\hline Total & 17 & 46,59 & & & & \\
\hline \multicolumn{7}{|l|}{ Umur 30 Hari } \\
\hline SK & DB & JK & KT & F Hitung & F1\% & F5\% \\
\hline Perlakuan & 5 & 44,93 & 8,98 & $5,87 * *$ & 5,64 & 3,33 \\
\hline Ulangan & 2 & 1,56 & & & & \\
\hline Acak & 10 & 15,34 & 1,53 & & & \\
\hline Total & 17 & 61,83 & & & & \\
\hline
\end{tabular}

Keterangan : * berbeda nyata

** berbeda sangat nyata 
Lampiran 3. Analisis Ragam Rata-Rata Berat Basah per Tanaman dan Berat Basah Tanaman per Polybag Kangkung Darat

\begin{tabular}{|c|c|c|c|c|c|c|}
\hline \multicolumn{7}{|l|}{ Sidik Ragam } \\
\hline SK & DB & $\mathrm{JK}$ & KT & F Hitung & F1\% & F5\% \\
\hline Perlakuan & 5 & 159,30 & 31,86 & 8,87 ** & 5,64 & 3,33 \\
\hline Ulangan & 2 & 22,25 & & & & \\
\hline Acak & 10 & 30,59 & 3,59 & & & \\
\hline Total & 17 & 212,14 & & & & \\
\hline \multicolumn{7}{|l|}{ Sidik Ragam } \\
\hline SK & $\mathrm{DB}$ & JK & KT & F Hitung & F1\% & F5\% \\
\hline Perlakuan & 5 & 14926,25 & 2985,25 & $13,11 * *$ & 5,64 & 3,33 \\
\hline Ulangan & 2 & 693,65 & & & & \\
\hline Acak & 10 & 2277,41 & 227,74 & & & \\
\hline Total & 17 & 17897,31 & & & & \\
\hline
\end{tabular}

